\title{
Between Cottage and Factory: The Evolution of Chinese and Japanese Silk-Reeling Industries in the Latter Half of the Nineteenth Century
}

\author{
DEBIN MA \\ GRIPS/FASID Joint Graduate Program, Shinjuku, Tokyo
}

ABSTRACT This article analyses the differential patterns of evolution in Chinese and Japanese silk-reeling industries during the latter half of the nineteenth century. It shows that, while Japanese exports of raw silk overall grew the fastest, the Guangdong region in China also expanded rapidly whereas the Lower Yangzi region lagged behind in machine-reeling production. This article applies a simple partial equilibrium framework to link the differential rates of growth with patterns of technological borrowing and economy-wide transaction costs. Through a historical narrative, the article argues that the contrasting performance in the two countries' silk exports is directly linked to the differential rates of decline in barriers to learning and transaction costs, which in turn were intimately associated with divergent political and economic changes taking place in Japan and China in the late nineteenth and early twentieth centuries.

KEY WORDS: China, Japan, silk, industrialization

JEL CLASSIFICATIONS: N15, N65

\section{Introduction}

In a classic poem taught to every school child in China, the famous Tang dynasty poet Li Shang-yin (813-858) mused that the silkworm was a selfless creature who spun silk for others until its last breath. This allegory is an apt depiction of the historical role of raw silk in developing Asia. Between 1850 and 1930, raw silk was the leading export item for Japan and China, accounting for 20-40\% of Japan's total exports and 20-30\% of China's exports (Li, 1981, p. 77; Yamazawa \& Yamamoto, 1979, p. 5). Revenue from raw silk exports supported the capital accumulation necessary for industrialization in both countries and, more importantly, sustained the livelihood of millions of workers and farm households raising silk cocoons. But it was the very

Correspondence Address: Dr. Debin Ma, GRIPS/FASID Joint Graduate Program, 2-2 Wakamatsu-cho, Shinjuku-ku, Tokyo 162-8677, Japan. E-mail: debinma@grips.ac.jp 
rise in living standards initially brought about by raw silk production that phased out the highly labour-intensive silk industry.

The development of modern Japan bears testimony to the historical role of raw silk. In 1873, China exported three times as much raw silk as Japan, but from 1905 Japanese raw silk exports exceeded Chinese exports and, in 1930, Japanese exports were three times those of China, gaining an $80 \%$ share of the world market. By 1970 , having long transcended the status of a developing economy, Japan turned from a one-time exporter to a net importer of raw silk.

The Japanese overtaking of Chinese silk production in the early twentieth century marked the first time China lost its lead since silk had been invented two millennia ago. And China had to wait until 1977, at the conclusion of more than two decades of political turmoil and economic isolation under Mao's rule, to recapture historical supremacy. By the 1990s, Chinese raw silk output exceeded Japan's historical record set in 1934, producing close to 70\% of the world total (Fujino et al., 1979, Table 55; Silk Bureau, 1966, pp. 89, 127 and 1990, p. 69; Xu, 1990, pp. 676-81; Wang \& Cu, 1992, pp. 325-330; Gu, 2001, p. 5).

The contrast between China and Japan is both puzzling and significant. By the midnineteenth century, when both countries emerged out of relative isolation, geography and factor endowments as well as global reputation all seemed to favour Chinese silk over that of Japan. Both countries had been deprived of tariff autonomy under similar unequal treaties imposed by Western imperial powers. The global market for raw silk was thrown wide open, especially after the pebrine crisis that devastated sericultural crops in Southern Europe around 1850. Global markets for raw silk were truly free and integrated.

This article argues that, to reap the full benefits of growing foreign demand, the traditional economies of China and Japan had to confront and overcome severe technological and organizational constraints that both posed barriers to learning and brought high transaction costs that directly and indirectly had on an impact on the rise of well-functioning markets for capital, labour and other inputs. Thus, the contrasting performance in the two countries' silk exports is directly linked to the differential rates of decline of barriers to learning and economy-wide transaction costs, which in turn were intimately associated with the divergent political and economic changes taking place in these two countries in the late nineteenth and early twentieth centuries.

This article focuses on the second half of the nineteenth century, a period of transition from hand-reeling to machine-reeling, where technical change and progress mostly involved borrowing and adaptation only. Restricting the study to this period enables me to concentrate on the role of learning, transaction costs and market development. I leave to future research the twentieth century, when major technological innovations occurred. The rest of the article is divided into three major sections followed by a summary. The first section gives a brief account of the main features of European and East Asian reeling technology, major quantitative trends and a partial equilibrium model. The second section provides a historical narrative about the 
process of transplanting European reeling technology to China and Japan. The third section summarizes differential regional patterns in the analytical framework of the model.

\section{Stylized Facts and Framework}

The twentieth-century eclipse of Chinese technological leadership in silk production by Japan in fact had an early modern historical precedent. Although it is beyond dispute that the prototype of the foot-treadle silk-reeling machine in Southern Europe was fundamentally Chinese, or more specifically, Lower Yangzi in origin, the French and Italian machines, aided by a series of subtle but crucial technological innovations, had risen to world leadership by the late seventeenth century. These innovations came to East Asia around 1850 as a bundle consisting of four new features.

The first one was the adoption of a rigid axle and cogwheel mechanism to transmit the power to move the reel in place of the driving-belt it had borrowed from China. The second one was the design of an additional twisting mechanism (Chambon style in France and Tavelle in Italy) to cross silk threads dry. The first mechanism stabilizes the reeling movement while the second innovation greatly enhances the cohesion, evenness and uniformity of the silk thread, features that are absolutely essential for high-quality raw silk (Zanier, 1994). The third one was the use of a centralized steam boiler that provided continuous and even heating for the reeling-basins of cocoons. The fourth one, which came last, was mechanization. However, use of steam power had not been crucial early on for the reeling of delicate silk threads - even in Europe, fully mechanized silk-reeling was largely a twentieth-century phenomenon. Therefore, the major distinction between hand- and machine-reeling in East Asia in the nineteenth century was the use of centralized steam heating.

Entrepreneurs in East Asia had selectively adopted various features of this bundle to suit their needs. For example, the traditional silk-reelers encountered little difficulty in inserting the first two features of European reeling technology - cogwheels and crossing systems - into their household-based production. However, the adoption of the third and fourth technical innovations required the use of a centralized location, a first step towards a modern factory. But even there, as will be shown below, various technological and organizational compromises had evolved in different periods so that the distinction between household and factory production becomes somewhat blurred in nineteenth-century East Asia. In comparison with other modern industries, silk-reeling factories remained relatively small in scale, low in capital intensity and dispersed in location.

The evenness and uniformity of the machine-reeled raw silk found favour with weavers in Europe and the United States whose production grew in scale and capital intensity. This product commanded a price premium over hand-reeled silk in the international market. Throughout the nineteenth and twentieth centuries, the average price for machine-reeled raw silk was about $40 \%$ higher than hand-reeled silk and 
Table 1. Raw silk exports of China and Japan by type (metric tons)

\begin{tabular}{lcccccr}
\hline Years & $\begin{array}{c}\text { Shanghai } \\
\text { hand }\end{array}$ & $\begin{array}{c}\text { Guangdong } \\
\text { hand }\end{array}$ & $\begin{array}{c}\text { Japan } \\
\text { hand }\end{array}$ & $\begin{array}{c}\text { Shanghai } \\
\text { machine }\end{array}$ & $\begin{array}{c}\text { Guangdong } \\
\text { machine }\end{array}$ & $\begin{array}{c}\text { Japan } \\
\text { machine }\end{array}$ \\
\hline $1880-90$ & 2370 & 345 & 1074 & - & 360 & 728 \\
$1890-1900$ & 2576 & 160 & 1010 & 484 & 1349 & 2358 \\
$1900-10$ & 1715 & 93 & 549 & 834 & 2097 & 5344 \\
$1910-20$ & 1320 & 127 & 153 & 1609 & 2206 & 11825 \\
$1920-30$ & 742 & 37 & 164 & 2306 & 2877 & 23989 \\
$1930-37$ & 236 & 42 & 229 & 1700 & 1599 & 30642 \\
\hline
\end{tabular}

Sources: Chinese raw silk data from Chen (1989, p. 170); Xu (1990, pp. 688-707). Guangdong handreeled silk from Wong (1995, pp. 290-291). Amounts of machine-reeled raw silk from Shanghai before 1894 were insignificant and not separately reported in the Maritime Customs Reports. Japanese raw silk data from Fujino et al. (1979, Tables 4-4 and 63). Hand-reeled silk 1879-1896 based on Ikawa (1992, p. 252), 1860-1867 based on Ishii (1972, p. 41).

$25 \%$ higher than the so-called improved hand-reeled raw silk, where an additional process of hand-re-reeling had been adopted (Fujino et al., 1979, p. 167).

Despite the price premium, the diffusion of machine-reeled silk did not result in an immediate displacement of hand-reeled silk in exports. Table 1 shows that exports of hand-reeled silk from China and Japan rivalled those of machine-reeled silk up to 1900 . Even in the twentieth century, machine-reeled silk predominated only in Japan and Guangdong, not in the Lower Yangzi. It is interesting to note that Guangdong had the highest share of exports of machine-reeled silk, followed closely by Japan (Figure 1). On the other hand, machine-reeled silk exports from the Lower Yangzi, the world's long-time leading high-quality silk-producing region, were so puny that they were not even separately counted in the 1893 trade statistics. Even by the 1920s, machine-reeled silk accounted only for about half of total exports from Shanghai.

To analyse the persistence of hand-reeled silk and the differential rate of diffusion of machine-reeling across these regions, I use a framework based on a simple partial equilibrium model with the demand side of raw silk set in the international market, i.e. with prices of machine-reeled and hand-reeled silk treated as parameters. For the supply side, there are two production functions for, respectively, machine-reeled and hand-reeled silk, each using three inputs: labour, reeling tools and cocoons. I further assume that both machine- and hand-reeling production incur a transaction cost per unit of output. Transaction costs here denote two broad categories of costs facing a silk-reeler. The first and most straightforward cost is that involved with marketing and moving silk, recruitment of labour, procurement of inputs, particularly cocoons. The second category pertains to the public and government sector in which the external legal environment, mechanisms for contract enforcement, security of property, and taxation policies are all likely to have an impact on transaction costs. It is reasonable to expect that a machine-reeled firm, with larger capital investment concentrated in a 


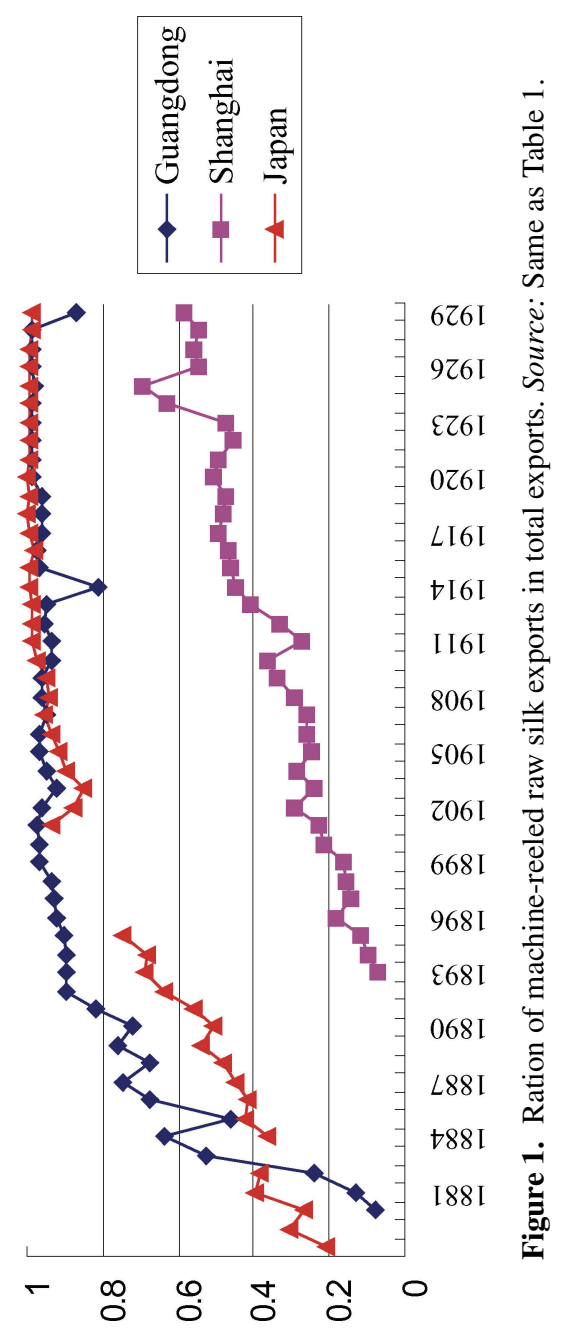


centralized location, is likely to incur higher transaction costs on both accounts per unit of output compared to a hand-reeling unit.

Combining the price of output, production functions and cost identities, we can derive different profit functions for machine- and hand-reeled silk. The intention of the model is that, although machine-reeled silk can be produced at a higher total factor productivity, fetching a higher price, it also requires more expensive machines, additional interest costs and higher per unit transaction costs. With CRS technology, perfect competition and a relatively inelastic cocoon supply, profit maximization with respect to inputs could yield a unique equilibrium output ratio of machine-reeled to hand-reeled silk, at which the optimal profit per unit of output for machine- and handreeled silk are equal given parameter restrictions. Comparative statistics would show the optimal output of machine-reeled silk to rise relative to that of hand-reeled silk if there is an increase in the price of machine-reeled silk, machine-reeling productivity, wage rates, or a decline in interest rates and the price of machine-reeling tools. Note that a decline in $T$, transaction cost per unit, will lead to an increase in both machineand hand-reeled silk output. It will increase machine-reeled silk proportionately more than hand-reeled silk so that, in the end, the ratio of machine-reeled over hand-reeled silk will rise.

This framework captures several important aspects of the transfer of European reeling technology and organization to traditional East Asian production. Despite the relatively high profitability and higher productivity of machine-reeling technology, a viable transplantation and diffusion of the new European technology required substantial learning efforts and, more importantly, a vigorous adaptation of a relatively expensive machine to the labour-abundant, capital-scarce economy of nineteenthcentury East Asia. Moreover, to produce in a centralized location, a modern factory, necessitated substantial reorganization and realignment of the existing social and economic structure in traditional East Asia. Being fundamentally rural-based, the success of modern silk-reeling industries hinged on the existing capacity of grass-root rural communities and agrarian structures to respond to these challenges and opportunities. As machine-reeling was often in direct competition with traditional handicraft interests, our analysis of its differential patterns of diffusion would have to be placed in the larger political economy context of these two countries at a critical junction that saw unprecedented political and economic shocks.

\section{European Technology in Nineteenth-Century East Asia}

\section{The Lower Yangzi}

We are able to trace the dramatic details of the first European silk-reeling technology transfer to East Asia through the rich archival records of East Asia's most powerful trading firm, Jardine, Matheson \& Co (Brown, 1979; Ishii, 1998). In 1859, Jardine employed a British subject, John Major, who had 15 years' experience of operating a silk filature in Naples, Italy. Major was eager to set up a similar factory in China 
applying 'Italian and French methods'. Construction began in 1860 in Shanghai, which since 1843 was open to Western trade. To construct a modern-style factory, complete with 100 machines driven by steam power and a warehouse, was no simple task in the then largely primitive 'frontier' environment of Shanghai. The factory was finished after a protracted and trouble-ridden 17 months.

Industrial capital and factory construction proved to be the easiest part of this modern factory, named 'Ewo Silk Filature'. To develop a stable workforce with sufficient skills and discipline, Major recruited four female skilled reelers directly from Lyon on five-year contracts. Despite initial setbacks and with all five French women having eloped with French soldiers within the first two years, a reasonably skilled Chinese female workforce evolved, consisting mainly of refugees from Nanjing ravaged by the Taiping rebellion. They turned out products of a quality that met European standards. The size of the factory also doubled to include an additional 100 reeling basins in 1863.

The real problem lay outside the factory or even outside Shanghai. The treaty port status of Shanghai provided Westerners and their business firms with extraterritorial protection. But the Ewo filature was set up with the presumption that Shanghai's hinterland, the Lower Yangzi delta, could serve as a reliable supply base of cocoons, the raw material for mechanized silk reeling. This presumption turned out to be fatal.

Worldwide, reeling factories were usually located near cocoon-producing regions since six times the amount of fresh cocoons are usually required to produce one unit of raw silk, i.e. transporting finished raw silk is far cheaper than shipping fresh cocoons. The choice of Shanghai, located more than 100 miles away from the sericultural region, as a site for production was clearly political since foreign direct investment was not allowed outside the treaty port area. Next to the higher transportation cost, Ewo immediately faced the technical problem of killing the chrysalis inside and drying the cocoons in the rural area. This technical problem was solved partially and gradually and paled in comparison with the political and social obstacles that Ewo encountered in the Chinese countryside. It was only in 1868 that Major, through repeated attempts and even mobilizing British diplomatic pressure, managed to set up a stable cocoon purchasing and drying station in the countryside. The fiercest resistance came from the organized silk handicraft and commercial guilds, fearing the loss of the source of cocoon supply.

In 1864, after a journey to purchase cocoon in the rural Yangzi region, Major recalled: 'I plainly saw that we must get rid of the Shanghai middleman and have a place upcountry to collect and kill cocoons. In following this up I had deadly opposition from these people and their friends upcountry, who for many years had been making a good thing of it and indeed from the whole silk guild. The mandarins were bribed to oppose me, people and brokers, more or less in the hands of the silk hongs frightened from me, suitable houses were refused me or set fire to, and what I actually built was pulled down and the Chinamen that did assist me were put in chains' (Brown, 1979, pp. 561-562). 
In the summer of 1869, Major for the first time was able to buy all the high-quality cocoons he required. But on another trip to the rural Lower Yangzi delta a couple of months later, he died of heat apoplexy. Soon afterwards, Jardine decided to close down the Ewo Filature as soon as the current inventory had been sold off. By May 1870, the Ewo, East Asia's first mechanized silk-reeling plant, closed after only ten years of operations. The history of the rise and fall of the Ewo filature seemed intricately linked to the tough-minded and single-willed personality of John Major. The reality was that the factory had been incurring a constant loss throughout its years of operations. The fixed costs of setting up an entire infrastructure to support a single factory were simply too high (Brown, 1979; Ishii, 1998, ch. 5).

The decade after the closure of Ewo passed without any further attempts being undertaken to set up mechanized silk-reeling in Shanghai. By the late 1870s, a new technological innovation of drying and storing fresh cocoons at the site of purchase was discovered (Xu, 1990, p. 129). This stirred up new interest in starting such factories. In the early 1880s, an American trading firm, Russell \& Co, and two other Western trading firms, established new filatures. In 1882, Jardine also came back, erecting a new Ewo filature. An important change of strategy was that the new Ewo factory enlisted the cooperation and capital of Chinese cocoon merchants who not only subscribed to the stocks but also sat on the board of directors (Suzuki, 1992, p. 324).

Most notably, in 1882, an eminent Chinese comprador of Western silk-trading firms, Huang Zhuoqin, started the first Chinese-owned filature. Huang's filature marked the beginning of a trend which brought the entire Shanghai silk industry into the hands of Chinese capital. It is important to note that Chinese investors preferred filatures registered as Western firms in order to obtain extraterritorial protection. Even in later years, reeling-firms fully owned and operated by Chinese businessmen were still registered as Western firms (Xu, 1990, p. 188; Suzuki, 1992, p. 324). This wave of factory construction increased production capacity in the nascent Shanghai silk industry to about 800 reeling basins (Suzuki, 1992, pp. 323-324).

These developments alarmed the traditional silk merchants in the Lower Yangzi delta. Through petitions and publications, they mobilized the local governors of Shanghai, and the provinces of Jiangsu and Zhejiang and, in September 1882, the authorities ordered the closure of the two Western silk-reeling factories in Shanghai. Their order, although rejected by the local British and American authorities that had jurisdiction over their areas of international settlement in Shanghai, sent stock prices of these two factories plunging and caused the closure of their rural cocoon station.

In 1883, Li Hongzhang, China's most powerful bureaucrat at the time, made a compromise and allowed the existence of these two Western silk-reeling factories in Shanghai. Subsequently, other Chinese-owned filatures were ordered to register with the authorities. One reason for the compromise was the government's levying of a transit tax, known as the likin tax, on cocoons purchased in the rural area. The opening of cocoon stations, like the silk hongs, would also be subject to official licence fees 
and taxes (Suzuki, 1992, pp. 329-332). By the mid-1880s, as revealed by Suzuki's painstaking research, there was a subtle but clear shift in government policy towards unofficial recognition of private silk-reeling firms (Suzuki, 1992, pp. 432-440). The industry began to recover and grew modestly so that, by the mid-1890s, there were more than ten factories, with about 3000-4000 reeling basins.

The mid-1880s policy shift did not constitute a major ideological change in the Self-strengthening Movement that discriminated against the private sector. In cotton spinning, for example, the government continued to prohibit private involvement largely because the government itself had been planning a mechanizing spinning plant. Similarly, attempts by Shanghai silk reelers and merchants at the same time to introduce steamships in the inner rivers were thwarted by local officials protecting the interests of traditional shipping. A major ideological shift came only after China's defeat by Japan in 1896, which eventually led to the lifting of all legal constraints on private enterprise. ${ }^{1}$

Different from the difficulties of machine-reeling in Shanghai, the response of the traditional hand-reeling sector in the rural Lower Yangzi to the new foreign demand seemed to be far more successful. To meet the European and American demand for evenness and uniformity, a new type of merchant firms, the so-called jinsihang, centred around Huzhou, Zheijang province, emerged in the 1870s to organize a re-reeling process, where hand-reeled silk collected from peasant households or silk hongs was first sorted by type, colour and grade. The sorted silk was then redistributed to the peasant households for re-reeling on a putting-out basis using newly invented rereeling tools. The jinsihang then packed the re-reeled silk for exports (Furuta, 1988, pp. 126-130; Zhu, 1985, pp. 142-145). Although still an imperfect substitute for machine-reeled silk, this product did not require technical or institutional changes beyond the traditional framework. Re-reeled silk was a clear improvement over traditional silk in overseas markets. It was important in explaining the resilience of hand-reeled silk exports from Shanghai in the nineteenth century.

\section{Guangdong}

A few years before John Major arrived in Shanghai to start his ill-fated filature, a poor and struggling part-time school-teacher of Confucian classics, named Chen Qiyuan, left his native Nanhai County in Guangdong for Southeast Asia. ${ }^{2}$ During the following ten years in Vietnam, Chen not only amassed a small fortune from his retail trade but also discovered the French-style filature operating in Vietnam. It was said that Chen travelled extensively in Vietnam and Thailand to carefully (and often surreptitiously) observe the machines, marking size and structure, using his own body as a frame of reference. In 1871, Chen returned to Nanhai with an elaborate plan to start a modern filature.

Unlike Major, however, Chen knew China, or at least his hometown. Beware of any possible interference by local authorities and guilds, he decided against such a 
conspicuous location as the city of Guangzhou (Canton). Instead, he set up his factory in Nanhai County. To fit a modern mechanized filature into a rural setting, Chen had to solve numerous technical problems. He reproduced the French-style reeling-machine with the two most crucial innovations of the European filature, the double-twisting mechanism and steam-heated oven. But he largely replaced the steel structures with locally available materials, such as wood, bamboo and china. He used a foot-powered treadle to allow human power to replace steam power and, to add a Chinese touch, used all-purpose Chinese chopsticks to pick out cocoons from the boiling basins (Wong, 1995, pp. 270-280).

To construct the machine and especially to adapt and install the steam boiler (for heating up the reeling basin) in the village, Chen engaged an ingenious traditional artisan in Guangzhou, who later became a main supplier of reeling machines in the area (Wong, 1995, p. 280). The modified machines were not only locally supplied but also much cheaper, costing about one-fifth of a Shanghai-style machine (Chen, 1985).

Mobilizing the lineage and village organization, he successfully recruited female workers in neighbouring areas. According to Suzuki, female workers of a particular factory were usually recruited from the same lineage-based village community sharing a common family name, whereas hiring from outside the lineage was discouraged (Suzuki, 1992, pp. 473, 480). ${ }^{3}$

Using credit advances and other tools, Chen also managed to procure cocoons from neighbouring markets. To market his raw silk, Chen set up special trading firms for selling directly to Western merchants. Modern filatures in Guangdong benefited from the multivoltine silkworms reared there, which would hatch four-six times a year, in contrast to only once or twice from the uni- or bi-voltine silkworms in Japan and the Lower Yangzi. Although somewhat inferior in quality, multivoltine silk production saved the financing cost of cocoon purchase and allowed year-round operation (see Sokoloff \& Dollar, 1997).

The factory started operations in 1874 after almost one year of preparations and construction. Unlike the Ewo in Shanghai, Chen's factory was said to have turned out profits even in its first year of operations. The filature product, much more smooth and even than traditional silk, was well received, fetching a price one-third higher than the hand-reeled product (Xu, 1990, p. 114).

Within a couple of years, Chen's factory expanded to about 800 basins. More importantly, Chen was keen to diffuse this technology, receiving, as he claimed, over 1000 visitors during the first three years of operations (Chen, 1989, p. 2). As a result, modern reeling factories spread quickly in Nanhai and the neighbouring Shunde County. By 1881, there were already 11 factories in Nanhai and six factories in Shunde with the total number of reeling basins exceeding 4000 (Xu, 1990, p. 116).

Understandably, China's first factory encountered resistance from both vested interests and traditionally minded locals. But Chen, through provision of local charity and participation in public projects, managed to pacify the discontent and gain the 
trust of the village elders. The growth of filatures occurred in Guangdong in China's characteristically ambiguous legal environment of which Chen Qiyuan took full advantage when using his social network. That very ambiguity, however, came back to haunt the industry at a later stage of development.

On 5 October 1881, a sacred day of sacrifice for the Nanhai silk weaver guild, more than 1000 weavers marched to destroy and loot a filature in the Nanhai County. On their way to Chen Qiyuan's factory, they clashed with local villagers defending the factory. The violence was said to have claimed two lives and wounded several hundreds. Although the weavers had long harboured anger towards the filatures, their Luddite violence was triggered by a particularly bad year of business. They blamed the filatures for taking away their source of cocoon supply.

Eventually, the local county militia had to be mobilized to put down the riot. The magistrate, while punishing the weavers for the violence, also ordered all filatures in the county to shut down immediately. The magistrate's ruling, backed by the provincial leader, was in line with the ruling ideology of the Self-strengthening Movement that discouraged private initiatives in modern industry. Appeals by Chen Qiyuan and others against the ruling failed. In 1882, Chen had to move his factory to the Portuguese colony of Macao. Filatures in the less conspicuous nearby Shunde County survived under the protective wings of the local gentry (Xu, 1990, pp. 121-123).

Fortunately, the policy shift of the Self-strengthening Movement in the mid-1880s in favour of private modern reeling firms came at the right time for Guangdong. Around 1886, the Qing government began levying taxes on the sale of machine-reeled silk, which was tantamount to an unofficial recognition of this type of production. Three years after the forced departure from Nanhai, Chen's factory was allowed back. But by then Shunde County was already on its way to becoming the new centre of growth. By 1894, Guangdong exported ten times more filature raw silk than in 1880 (Suzuki, 1992, pp. 419-447; Xu, 1990, p. 127).

At the time when Chen Qiyuan designed the steam-heated reeling-machine, he also made a model complete with the French Chambon double-crossing system that, for heating, used a charcoal stove instead of centralized steam-boiling. This model, which did not require a concentration of equipment in a centralized location, was an instant success. It diffused quickly among individual peasant households and was later adopted by merchants in a variety of organizational forms, including putting-out and a 'manufactories' system. Part of this 'improved' hand-reeled silk went for export but the bulk catered to the domestic market (Xu, 1990, pp. 126-127).

\section{Japan}

Japanese modern filature started exactly where the first Shanghai Ewo filature left off. The Jardine trading firm was considering setting up a modern filature in Japan in the late 1860s. Meanwhile, in 1869, the Maebashi-han sent an official, Hayami Kenzou, to Yokohama to investigate foreign demand for raw silk. Visiting the Swiss embassy, 
Hayami was shocked to find that Japanese raw silk was selling in London at half the price of Italian and French raw silk. This brought home the urgency of improving the quality of Japanese raw silk by adopting European methods of production (Furuta, 1988, p. 138).

In 1869, the year that Major died in the rural Lower Yangzi, Maebashi-han officials visited Jardine's Yokohama office and soon after started negotiations about transferring the reeling machines of the ill-fated Shanghai Ewo filature to start up a joint venture in Maebashi. The negotiations did not succeed. The Maebashi-han officials decided to independently start a modern filature with the purchase of Italian-style machinery from a Swiss trading firm in Yokohama. After receiving approval from the newly established foreign ministry of the Meiji government, the han officials employed a Western technical supervisor recommended by the trading firm (Ishii, 1998, p. 182; Furuta, 1988, p. 139).

Japan's first modern filature thus started in 1870 with 12 machines. The machinery was initially set up in the middle of Maebashi in June but it encountered fierce resistance from local officials and merchants fearing the loss of their handicraft interests. Three months later, the filature had to be relocated to the isolated village of Iwagami, with Hayami himself having endured threats of assassination. The machine adopted the Italian self-crossing Tavelle system (also referred to as kenneru in Japan) and centralized steam heating, but was greatly modified to suit local conditions - wood replaced metal for the reeling basin, steam-power was replaced by human and later water-power. During the four-months when Casper Mueller, the technical advisor, was under contract, Hayami and a few other people worked around the clock to grasp the technology (Furuta, 1988, p. 139-140; Dai Nihon, 1936, pp. 50-51).

The Maebashi filature never truly became a viable and self-sustaining business and, with the abolishment of han officialdom under Meiji's centralization policy in 1872 , it was taken over by the Gunma prefecture that later sold it to the merchant house Ono-gumi. In 1871, however, Ono-gumi launched a reeling factory in Tsukiji in metropolitan Tokyo with 60 filatures partly because, Mueller, who was again hired as technical supervisor, feared working in the countryside (Furuta, 1988, p. 76). This urban-based private operation was even more short-lived and closed down in June 1873 partly due to the disappearance of mulberry fields and cocoon supply in rapidly urbanizing Tokyo (Furuta, 1988, p. 76).

These two early efforts to introduce European reeling technology were followed by the third and the most well-known initiatives taken by the Meiji government itself, the Tomioka silk-reeling mill in Gunma prefecture in October 1872. This factory, owned and operated by the government, had 300 iron-made reeling machines driven by steampower and housed under a specially constructed Western-style red-brick building. It became an imposing structure in rural nineteenth-century Japan (Kiyokawa, 1987, p. 29). It also brought in Paul Brunat as head advisor along with 11 experts, i.e. two foremen, three assistants, four female reeling supervisors, one machinist and one physician who were all brought in directly from France (Kiyokawa, 1987, p. 29). 
Despite government sanction, the construction of the factory met with local xenophobic resistance. When the factory started recruiting workers in March 1872, few people applied. Eventually, through repeated assurances from the government, the factory managed to employ female workers on a two-year rotation basis from various parts of Japan. The Tomioka's transfer of the full bundle of European technology, irrespective of local conditions, was reminiscent of John Major's Ewo filature backed by Jardine's financial capital. And like Ewo, the Tomioka factory was a financial failure and was sold off in the 1880s by the government at a price lower than the original investment. The idealized French filature proved to be unrealistic for the relatively primitive state of the Japanese economy. Japanese cocoons rarely met the quality standards required by Tomioka. The machines, spare parts and repairs were extremely costly (Kiyokawa, 1987, pp. 34-36; Tsurumi, 1990, ch. 2).

The trajectory of Japanese reeling technology and organization was to follow the path pioneered by the Maebashi and the Tsukiji filatures rather than that of the Tomioka. In August 1872, even before the closure of its urban-based Tsukiji filature, Ono-gumi launched a modern filature in the Upper Suwa area of Nagano Prefecture using technical supervisors transferred from the Tsukiji filatures. Ono-gumi also engaged in financing several other filatures in rural Nagano. In 1874, when Onogumi itself went bankrupt, the seeds of filature reeling were already sown as Suwa in Nagano was soon to become Japan's centre of silk-reeling industry (Furuta, 1988, pp. 77-78; Dai Nihon, 1936, pp. 52-53).

However, most of these family-based filatures were fairly small in scale and often produced an amount of raw silk below the minimum order from the retail merchants in Yokohama. To overcome this problem, rural-based filatures were organized as sha, a type of village-based cooperative each usually consisting of 10-20 kumi, individually owned and operated filatures. The members of the cooperative would supervise each other's production to ensure homogeneity and standards in quality and jointly market their finished raw silk to Yokohama under their sha label. They also coordinated the purchase of cocoons and employment of female labourers. Moreover, the cooperatives were units of what we now know as joint-liability lending, through which they acquired direct credit advances, mostly for purchases of cocoons, from the wholesale merchants in Yokohama (see further Hayami, 1998). By the second half of the 1880s, most of the cooperatives were equipped with a joint re-reeling plant specialized in sorting and re-reeling raw silk produced by the individual member filature to achieve greater standardization for shipment to Yokohama.

This system of production, combining indigenous social organization with borrowed intermediary technology, supported the rapid growth in exports of machinereeled silk in the late nineteenth century. In the 1890s there were signs that the system may have outgrown itself. In 1895, the filature group under the Katakura family withdrew from Kaimeisha, the largest cooperative in Suwa, and independently started its own reeling factory with 360 basins. This marked the beginning of the rise of 
independent manufacturers. With the growth of filatures, it became increasingly difficult for cooperatives, with their disparate production units sometimes employing different power sources, to rely only on the final process of re-reeling for standardization. In the case of the Katakura factory, which had consistently produced relatively high-quality silk, there was a strong incentive to strike out on its own to fully capture the quality premium.

Equally important to this Japanese transition to independent manufacturers was the surge of filatures in Shanghai following the lifting of legal constraints against private capital in modern business in 1896. The relatively large-scale independent filatures in Shanghai were turning out machine-reeled raw silk with a good reputation in the international market. Hence, the rise of the modern factory was a direct response to overseas competition (Nakabayashi, 2003, ch. 4).

It is important to recognize that the divisibility of the bundle of European technology could, as in the case of Guangdong, also exert a transformational effect on Japan's hand-reeling industry. In the 1870s, Japanese reelers already began improving their traditional hand-reeling machines through the addition of the foottreadle, the cogwheel and the crossing-system (mostly the Italian Tavelle style) (Fujino et al., 1979, p. 167). Without the use of steam-heating and inanimate power, the improved hand-reeling machines (referred to as improved zaguri) did not require operations at a centralized location and there diffused rapidly among peasant households.

To satisfy Western demand for uniformity, traditional hand-reelers and merchants also adopted the re-reeling process. While organizational forms such as putting-out were also adopted on a fairly substantial scale, the prevalent unit of production was the cooperative, sha or kumi, system, similar to that in the machine-reeled sector. Ironically, it was the Gunma prefecture - the region where Tomioka was located that rose to become the centre of cooperative-based hand-reeling production. Each cooperative, as in the machine-reeling system, shared centralized joint re-reeling plants but the initial reeling process was usually done at the individual household rather than the filature level. They also coordinated the hiring of labourers, marketing and credit procurement. In comparison to machine-reeling production, the scale of operations was smaller and production was more self-sufficient, with cocoons often raised domestically. In spite of this, the improved hand-reeling production proved a viable and important system of production in nineteenth-century Japan.

\section{The Determinants of Regional Differences: A Summary Hypothesis}

As demonstrated by the narrative above, innovative adaptation of European technology to the local physical and social environment ensured the rapid diffusion of machine-reeling in Guangdong and Japan in the late nineteenth century. This success, contrasted by the laggard diffusion of machine-reeling in Shanghai due to the 
absence of technological adaptation, reveals the important role of creative technical learning for the growth in silk exports. This is consistent with our model prediction that a reduction in the price of a machine-reel tool will lead to a higher output of machine-reeled silk compared with hand-reeled silk.

Differentiation at other levels of technological diffusion also took place in the three regions surveyed. Shanghai, through foreign direct investment, and Japan, through efforts by central and local governments and private entrepreneurs, were exposed to the most advanced Italian silk reeling technology. By contrast, Guangdong, through a private individual like Chen Qiyuan, learnt of the French technology through a secondhand or even third-hand source. There is a possibility that Western reeling technology in Vietnam witnessed by Chen may have been indirectly transferred from Western entrepreneurs in Bengal, India. The cogwheel mechanism, which could have been dropped in the Bengal adaptation, was conspicuously absent in Chen's drawings. More importantly, the French Chambon system adapted was relatively outdated compared with the Italian Tavelle system, but Guangdong was to stick to it into the twentieth century. Apparently, the channels through which knowledge was transferred had longterm implications for productivity.

Machines however were only part of the story. Machine-reeling shifted the reeling process out of individual peasant households. In comparison with traditional handreeling, modern filatures are far more dependent on market transactions. Cocoons accounted for $60-80 \%$ of the value added of raw silk. As is true throughout China and Japan, modern filatures relied heavily on short-term finance. The growth of silkreeling in Suwa, Nagano, for example, was a tale of financial expansion. In the 1870s, and early 1880s, a financial network based on credit advance linked the Yokohama silk merchants with reeling cooperatives in the mountainous Nagano. This system of credit provision relied on the use of bills of exchange and the network of national banks set up and diffused across rural Japan since the Meiji restoration. By the late 1870 s, the issue of insurance contracts by domestic land-transportation corporations further reduced the risk of lending. In the mid-1880s, the Yokohama Specie Bank and later the newly established Bank of Japan, provided low-interest indirect finance to the silk reelers through rediscounting bills held by Yokohama merchants and local banks (Nakabayashi, 2003, ch. 7).

Consistent with our model predictions, a general decline in interest rates would lead to a higher level of machine-reeling production. But the interest rate story is also part of the transaction cost explanation included in our model. An essential element supporting the expansion of Japanese reeling industry in the nineteenth century was the rapidly improving external infrastructure built up in the Meiji period. Newly built modern communication systems such as the telegraph between Tokyo and silk-producing regions reduced the power of local silk merchants and enhanced the interests of silk-producing cooperatives. Before the modern telegraph reached rural Japan, local silk merchants in Maebashi used to hire runners to acquire price information from Yokohama. Such activities, profiting from price differentials 
between Maebashi and Yokohama, vanished soon after the telegraph was installed in the late 1870s. Apart from the government policies mentioned above, this is a major reason for the decline of local silk merchants (Ishii, 1972, pp. 100-101). Infrastructure construction or improvements of roads, shipping lines and railroads, continuing from the 1870s onwards, not only served to link the rural silk-producing regions with Yokohama but also helped filatures to extend their cocoon purchase to locations further away from the immediate surroundings (Nakabayashi, 2003, ch. 3).

In the Lower Yangzi, a dense financial network composed of foreign banks, trading firms and domestic banks clustered in the treaty port of Shanghai, but financial intermediaries beyond Shanghai were few and far between until the 1920s. At each cocoon purchasing season, silk reelers had to organize shipments of bulky silver ingots guarded by military boats to the rural Lower Yangzi for cocoon procurement (Chen, 1989, pp. 79-80). The construction of railroads had to wait until the early twentieth century and it was even later in Guangdong (Ma, 2004).

To understand fully the differential rate of decline in transaction costs, one cannot avoid the wider political economy context. Both Guangdong and Lower Yangzi turned out to be a hazardous and sometimes dangerous environment for capital investment in concentrated locations. Due to the insecurity of private investment in machine-reeling, in terms of location, Shanghai became a centre of the reeling industry for very much the wrong reasons, enduring high transactions costs from beginning to end.

In the clash between traditional handicraft and modern factory interests, Qing's initial stance in favour of the traditional was not merely ideological. In the latter half of the nineteenth century, public finance in Qing China deteriorated rapidly and government revenue grew dependent on commercial taxes, such as the likin tax. Merchants suffered an increasing squeeze. In return for tax revenue, merchant guilds through tax farming extracted monopoly power from the government, a process in which both parties ended up being captives of vested interests (Ma, 2004).

The retreat of Japanese mercantile control in the nineteenth century is highly illuminating. In 1873, in order to arrest the trend of quality deterioration in raw silk exports, the Meiji government promulgated the Regulation on Raw Silk Production stipulating that all raw silk bound for exports would have to bear government-printed labels and that all silk merchants were required to obtain a licence from the Ministry of Finance. Subsequently, the government organized a national Aratame Kaisha (Raw Silk Corporation) with branches in all major silk-producing regions. Licensed silk merchants entrusted with raw silk quality inspection and the distribution of government labels soon came to dominate the Aratame Kaisha at the local level.

The Aratame Kaisha, designed for quality control and possibly also used as a blocking device against the intrusion of Western trading firms into rural Japan, inadvertently resulted in the rise of a privileged merchant group that, backed by government power, began to exercise monopoly control over the silk trade in Japan. In 1876, Hayami Kenzou, then an official in the government industrial promotion bureau, voiced his 
concern about the Aratame Kaisha becoming a hindrance to the development of the embryonic machine-reeling filature in rural Japan. In 1877, the government officially withdrew the Regulation but it took another four years for the entire system of Aratame Kaisha to whither away. During this period, the government stood firm against repeated attempts by local silk merchants to regain their trading privileges and their attempts to include machine-reeled raw silk under their monopsony control. It was the weakening of local merchant monopolies that paved the way for silk-reeling cooperatives and later factories to establish direct trading relationships with the retail merchants in Yokohama (Ishii, 1972, pp. 96-115).

The study of the evolution of the silk industry offers us important insights, not only into the impact of political change on economic growth, but also new light is shed on the nature of traditional East Asian society. It is important to recognize that the transaction costs modelled in this article were largely beyond the control of individual firms or households. Thus, to overcome them, coordination was required on a local or, in many cases, the national level. This case study of raw silk exports is thus an interesting counter-test to the burgeoning literature spawned by a seminal article in 1989 on industrialization and the 'Big Push', stressing the crucial importance of coordinated investment through demand-side spillovers in the domestic market (Murphy et al., 1989). The 'Big Push'-idea, originally formulated by Rosenstein-Rodan in the 1940 s, became the intellectual foundation for post-war import-substitution policies pursued by many developing countries.

\section{Acknowledgements}

This article benefited greatly from comments by and discussion with Claudio Zanier, Masayuki Tanimoto, Yukihiko Kiyokwa, Futoshi Yamauchi, Tetsushi Sonobe, Thomas Lindblad and Keijiro Otsuka. Funding from the Leadership Research grants of the Hitotsubashi University is gratefully acknowledged. The author alone is responsible for all errors.

\section{Notes}

1. Under the treaty system, steamships were allowed to ply the Yangzi river and the coast but not the inner rivers of canals. The government only compromised in 1889 by granting use of steamers in towing traditional boats (Suzuki, 1992, p. 347).

2. Sources for this narrative include two publications by the Historical Archives Committee of the Nanhai County, Political Consultative Committee of Guangdong Province, A Special Issue on Chen Qiyuan and Nanhai Textile Industry History (1987) and Cuanshanbu Zuanqi [Special Issue on Sericultural Manual by Chen Qiyuan] in 1994.

3. See Faure (1989) on the important role of lineage as a social and economic organization.

\section{References}

Brown, Sh. R. (1979) The Ewo filature: a study in the transfer of technology to China in the nineteenth century, Technology and Culture, 20(3), pp. 550-568. 
Chen Yao-Min (1985) Qing Mu Shunde Jiqi Cao Si Ye De Cai Sheng, Fa Zhan Jiqi Ying Xiang (in Chinese) [The beginning, development and significance of machine-reeling industry in late-Qing Shunde] in: Historical Association of Guangdong (ed.) Ming Qing Guangdong SheHui ChinJi XingTai YanJiu [Studies on the Socio-Economic Conditions of Ming and Qing Guangdong] (Guangdong: Guangdong People's Publishing House).

Chen Zi-yu (1989) Jingdai Zhongguo de Jijie Saosi Gongye, 1860-1945 (in Chinese) [The Silk Industry of Modern China, 1860-1945] (Taipei: Academia Sinica).

Dai Nihon (1936) Nihon Sanshigyo Shi, Vol. 2 (in Japanese) (Tokyo: Editing Committee of the Dai Nihon Sanshigyo Shi).

Faure, D. (1989) The lineage as business company, in: R.A. Brown (ed.) Chinese Business Enterprises. Critical Perspectives on Business and Management (London: Routledge).

Fujino, Shozaburo, Fujino, Shiro \& Ono, Akira (1979) Estimates of Long-Term Economic Statistics of Japan since 1868: Vol. 11 (in Japanese) (Tokyo: Toyo Keizai Shinposha).

Furuta Kazuko (1988) Technology transfer and local adaptation: the case of silk-reeling in modern East Asia, unpublished $\mathrm{PhD}$ dissertation, Princeton University.

Gu, Guoda (2001) Sericultural Economy and Silk Trade of the World (in Chinese) (Beijing: Chinese Agricultural Technology Press).

Hayami, Yujiro (ed.) (1998) Toward the Rural-Based Development of Commerce and Industry. Selected Experiences from East Asia (Washington, DC: World Bank).

Ikawa, Katsuhiko (1992) Seishi-gyo to America Sijo (in Japanese) [Raw silk sector and the American market], in: Naosuke Takamura (ed.) Kigyo Bokko: Nihon Shihonshugi No Keisei [The Rise of Firms: The Formation of Japanese Capitalism] (Kyoto: Mineruva Shobo).

Ishii, Kanji (1972) Nihon Sanshi-gyo Shi Bunseki (in Japanese) [Analysis of Japanese Silk Industry] (Tokyo: Tokyo Daigaku Shuppankai).

Ishii, Mayako (1998) Kindai Chugoku to Igirisi Shihon (in Japanese) [Modern China and British Capital) (Tokyo: University of Tokyo Press).

Kiyokawa, Yukihiko (1987) Transplantation of the European factory system and adaptations in Japan: the experience of the Tomioka model filature, Hitotsubashi Journal of Economics, 28, pp. 2739.

Li, L. M. (1981) China's Silk trade: Traditional Industry in the Modern World, 1842-1937 (Cambridge, MA: Council on East Asian Studies, Harvard University).

Ma, D. (2004) Why Japan, not China, was the first to develop in East Asia: lessons from sericulture 1850-1939, Economic Development and Cultural Change, 52(2).

Murphy, K., Shleifer, A. \& Vishny, R. (1989) Industrialization and the Big Push, Journal of Political Economy, 97.

Nakabayashi, Masaki (2003) Kindai Shihon Shugi No Soushiki (in Japanese) [Organization in Modern Capitalist: Governance of Trade and Production in the Silk Reeling Industry] (Tokyo: University of Tokyo Press).

Silk Bureau (1966, 1990) SanshiGyou Yoran (in Japanese) (Tokyo: Japanese Sericultural Associated Press).

Sokoloff, K. \& Dollar, D. (1997) Agricultural seasonality and the organization of manufacturing in early industrial economies: the contrast between England and the United States, Journal of Economic History, 57(2), 288-321.

Suzuki, Tomoo (1992) Yomu Undo No Kenkyu (in Japanese) [A Study of the Westernization Movement in China in the latter Half of the Nineteenth Century] (Tokyo: Kyuko Shoin).

Tsurumi, E. P. (1990) Factory Girls: Women in the Thread Mills of Meiji Japan (Princeton, NJ: Princeton University Press).

Wang, Z. M. \& Cu, Q. M. (1992) Xin Zhongguo Sicou Dasiji (in Chinese) [Chronicles of Sillk in New China] (Beijing: Textile Industry Press).

Wong, Chor Yee (1995) Proto-industrialization and the silk industry of the Canton Delta, 1662-1934, unpublished $\mathrm{PhD}$ dissertation, University of Wisconsin, Madison. 
Xu, Xin-wu (ed.) (1990) Zhongguo Jindai Saosi Gongyeshi (in Chinese) [Modern History of Chinese Silk-reeling Industry] (Shanghai: People's Publishing House).

Yamazawa, I. \& Yamamoto, Y. (1979) Estimates of Long-Term Economic Statistics of Japan since 1868: Vol. 14 (in Japanese) (Tokyo: Toyo Keizai Shinposha).

Zanier, C. (1994) Where the Roads Meet: East and West in the Silk Production Processes (17th to 19th Century) (Kyoto: Istituto Italiano di Cultura Scuola di Studi sull'Asia Orientale).

Zhu, Xinyu (ed.) (1985) Zhejiang Sicou Si (in Chinese) [History of Zhejiang Silk] (Hanzhou: Zhejiang People's Press). 